\title{
IMPLEMENTASI PRINSIP-PRINSIP DEMOKRASI DALAM PEMILIHAN REKTOR IKIP PGRI PONTIANAK
}

\author{
Fety Novianty $^{1}$, Sulha ${ }^{2}$, Lisa Angraini Febriyanti ${ }^{3}$ \\ 1,2,3Program Studi PPKN Fakultas Ilmu Pendidikan dan Pengetahuan Sosial IKIP PGRI Pontianak \\ Jl. Ampera Nomor 88 Pontianak-78116, Telepon (0561) 748219 Fax. (0561) 6589855 \\ Email: putrikhanza96@yahoo.co.id
}

\begin{abstract}
Abstrak
Penelitian ini dilaksanakan dengan tujuan memperoleh informasi serta kejelasan tentangimplementasi prinsipprinsip demokrasidalam pemilihan rektor IKIP PGRI Pontianak. Secara khusus dalam penelitian ini adalah untuk mengetahui secara rinci mengenai Bentuk prinsip-prinsip demokrasi dalam pemilihan rektor IKIP PGRI Pontianak, Pelaksanaan demokrasi di IKIP PGRIPontianak., dan Faktor yang mempengaruhi implementasi prinsip-prinsip demokrasidalam pemilihan rektor IKIP PGRI Pontianak. Pendekatan penelitian yang dilakukan adalah kualitatif dengan bentuk penelitian terapan. Teknik pengumpulan data yang digunakan adalah komunikasi langsung, observasi langsung dan studi documenter dengan alat pengumpul datanya adalah pedoman wawancara, pedoman observasi dan dokumen. Teknik analisis data yang digunakan adalah secara kualitatif yaitu dengan pengumpulan data, reduksi data, penyajian data, dan verifikasi atau penarikan kesimpulan. Hasil penelitian secara umum pelaksanaan pemilihan Rektor di Kampus IKIP PGRI Pontianak sudah dapat berjalan dengan baik. Bentuk demokrasi yang dilaksanakan dalam pemilihan ini adalah bentuk demokrasi perwakilan,. Faktor Yang Mempengaruhi Implementasi Prinsip-Prinsip Demokrasi dalam Pemilihan Rektor IKIP PGRI Pontianak dapat di kondisikan dengan baik, hal ini dapat dilihat dari: a) pelaksanaan pemilihan rektor dilakukan dengan asas keterbukaan karena semuanya kita sampaikan lewat rapat maupun dalam pemilihan dan diikuti oleh anggota senat, b) ada mekanisme pemilihan jadi tidak semua dosen ikut dalam pemilihan. c) semua pemilih memiliki persamaan dan kesetaraan tidak ada yang kita beda-bedakan dalam pemilihan rektor. d) Kebebasan menjadi landasan dalam pemilihan rektordengan mengikuti STATUTA IKIP PGRI Pontianak, contohnya saja kebebasan dalam menentukan calon rektor yang mereka pilih. e) Prinsip kontrol terus dilakukan pada tugas dan kinerja rektor terpilih supaya tidak ada hal yang tidak di inginkan terjadi di lembaga.
\end{abstract}

Kata Kunci : Prinsip-prinsip demokrasi, pemilihan rektor

\begin{abstract}
This research was conducted with the aim of obtaining information and clarity about the implementation of democratic principles in the election of the Chancellor of the IKIP PGRI Pontianak. Specifically in this study is to find out in detail about the Forms of democratic principles in the election of the Chancellor of the IKIP PGRI Pontianak, The implementation of democracy in IKIP PGRI Pontianak, and Factors that influence the implementation of democratic principles in the election of the Chancellor of the IKIP PGRI Pontianak. The research approach taken is qualitative with the form of applied research. Data collection techniques used are direct communication, direct observation and documentary studies with data collection tools are interview guidelines, observation guidelines and documents. The data analysis technique used is qualitatively, namely by collecting data, reducing data, presenting data, and verifying or drawing conclusions. In general, the results of the research on the selection of the Chancellor at the IKIP PGRI Pontianak Campus have been able to run well. The form of democracy carried out in this election is a form of representative democracy. Factors that influence the implementation of democratic principles in the selection of Pontianak Chancellors of IKIP-PGR can be well characterized, this can be seen from: a) the implementation of the chancellor election is carried out with the principle of openness because everything we convey through meetings and in elections and followed by senate members, $b$ ) there is an election mechanism so not all lecturers participate in the election, c) all voters have equality and equality that we do not differentiate in the election of the chancellor, d) Freedom becomes the foundation in the selection of rectangles by following the Pontianak STATUTA of IKIP PGRI, for example, the freedom to determine their chosen chancellor candidates, $e$ ) The principle of control continues to be carried out on the duties and performance of the elected chancellor so that nothing that is not desired happens at the institution.
\end{abstract}

Keywords: Principles of democracy, chancellor election 


\section{PENDAHULUAN}

Budiyanto (2007:33) mengemukakan demokrasi adalah sistem pemerintahan yang diselenggarakan dari rakyat, oleh rakyat dan untuk rakyat. Hannry B. Mayo mengemukakan kebijaksanaan umum ditentukan atas dasar mayoritas oleh wakil-wakil yang diawasi secara efektif oleh rakyat dalam pemilihan-pemilihan yang didasarkan atas prinsip kesamaan politik dan diselenggarakan dalam suasana dimana terjadi kebebasan politik. Hamid Darmadi, (2007:172) mengemukakan“demokrasi Indonesia tertuang dalam UUD 1945 yang mengandung pengertian rakyat adalah unsur sentral dalam pembinaan dan pengembangan dengan orientasi baik dalam nilai-nilai universal, rasionalisme hukum dan perundang-undangan juga ditunjang norma-norma kemasyarakatan yaitu tuntutan dan kehendak yang berkembang dalam masyarakat”.

Budiyanto, (2007:38) mengemukakan negara dengan sistem politik demokrasi umumnya ditandai oleh ciri-ciri sebagai berikut: 1) Adanya pembatasan terhadap tindakan pemerintah untuk memberikan perlindungan bagi individu dan kelompok, dalam penyelenggaraan pergantian pimpinan secara berkala, tertib, damai dan melalui alat perwakilan rakyat yang efektif. Pembatasan ini tidak berarti bahwa tidak adanya campur tangan pemerintah dalam aspek kehidupan, sepanjang undang-undang memberikan kewenangan untuk itu. 2)Prasaranan pendapat umum baik pers, televisi dan radio harus diberikan kesempatan untuk mencari berita secara kebebasan untuk mengeluarkan pendapat, berserikat dan berkumpul merupakan hak-hak politik dan sipil yang sangat mendasar. 3)Sikap menghargai hak-hak minoritas dan perorangan, lebih mengutamakan musyawarah dari pada paksaan dalam menyelesaikan perselisihan, sikap menerima legitimasi dari sistem pemerintahan.

Samuel Huntington mengemukakan demokrasi ada jika para pembuat keputusan kolektif yang paling kuat dalam sebuah sistem dipilih melalui suatu pemilihan umum yang adil, jujur dan berkala dan di dalam sistem itu para calon bebas bersaing untuk memperoleh suara dan hampir seluruh penduduk dewasa dapat memberikan suara karena kebebasan di jamin oleh negara.Selain itu kebebasan memilih dan berpendapat merupakan hak setiap individu sejak dilahirkan yang telah dijamin oleh konstitusi. Oleh karena itu, Negara Republik Indonesia sebagai negara hukum dan demokratis berwenang untuk mengatur dan melindungi pelaksanaannya. Kemerdekaan berpikir dan mengeluarkan pendapat tersebut diatur dalam perubahan keempat Undang-Undang Dasar Republik Indonesia tahun 1945 Pasal 28 E ayat (3) Setiap orang berhak atas kebebasan berserikat, berkumpul, dan mengeluarkan pendapat. Kebebasan berekspresi termasuk kebebasan berpendapat merupakan salah satu hak paling mendasar dalam kehidupan bernegara. Undang-undang No. 9 Tahun 1998 tentang Kemerdekaan Menyampaikan Pendapat di muka umum pasal 1 ayat (1) kemerdekaan menyampaikan pendapat adalah hak setiap warga negara untuk menyampaikan 
pikiran dengan lisan, tulisan, dan sebagainya secara bebas dan bertanggung jawab sesuai dengan ketentuan peraturan perundang-undangan yang berlaku.

Indonesia merupakan negara hukum tentu saja memiliki peraturan yang melindungi hak-hak asasi manusia. Kehadiran hak asasi manusia sebenarnya tidak diberikan oleh negara, melainkan asasi manusia menurut hipotesis John Locke merupakan hak-hak individu yang sifatnya kodrati, dimiliki oleh setiap insansejak ia lahir. Salah satunya adalah hak berbicara dan mengeluarkan pendapat yang dimiliki oleh setiap masyarakat Indonesia tanpa memandang suku, ras dan agama.Kebebasan berbicara dan mengeluarkan pendapat dapat dilakukan dalam berbagai bentuk.Misalnya saja tulisan, buku, diskusi, artikel dan berbagai media lainnya.Semakin dewasa suatu bangsa maka kebebasan berbicara dan mengeluarkan pendapat semakin dihormati.

Terkait dengan prinsip-prinsip demokrasi, sesunguhnya prinsip-prinsip demokrasi sejalan dengan prinsip-prinsip kerukunan umat beragama. Karena demokrasi bukan hanya merupakan metode kekuasaan mayoritas melalu partisipasi rakyat dan kompetisi bebas, tetapi juga mengandung nilai-nilai universal, seperti persamaan, kebebasan, keadilan, pluralisme, termasuk tanggung-jawab.Nilai-nilai ini pulalah yang menjadi dasar perhatian dalam agama-agama.Apalagi eksistensi demokrasi juga berkaitan dengan eksistensi Hak-Hak Azasi Manusia (HAM).

Hal yang amat beresiko dalam pesta demokrasi seperti pada pemilihandaerah atau lembaga adalah tampilnya sejumlah kandidat yang banyak jumlahnya.Hampir disetiap kelompok pendukung suatu calon"memanfaatkan" atau menggunakan karisma tokoh atau calon.Dalam hal ini tim sukses menempati barisan terdepan dalam mensosialisasikan program-program kerja calon atau kandidat. Tim sukses sekaligus diharapkan dapat mengarahkan "pendukung"nya untuk memilih calon atau kandidat yang didukung. Jadi posisitimsukses di sini sangat sentral, sekaligus menjadi penentu pemenangan suatu calon atau kandidat.

Secara umum pemilihan rektor perguruan tinggi negeri (PTN) maupun pemilihan rektor perguruan tinggi swasta (PTS) dalam beberapa hari terakhir menjadi sorotan sejumlah media massa. Hal ini berwal tahun 1985 terbit Perpres Nomor 9. Berdasarkan regulasi ini, rektor merupakan pejabat struktural setara dengan eselon I sehingga yang menetapkannya adalah presiden dan yang melantik adalah menteri.Ini berjalan terus. Tahun 2007 keluar Perpres Nomor 65, yang tadinya rektor merupakan pejabat eselon I, kemudian berubah, Rektor sebagai tugas tambahan, bukan sebagai eselon I. Karena sebagai tugas tambahan, yang menetapkan adalah menteri. Tahun 2010 terbit Permendiknas Nomor 24 yang mengatur tata cara pemilihan rektor, yakni suara menteri $35 \%$, sedangkan suara anggota senat $65 \%$. Seiring dengan berjalannya waktu, dilakukan perbaikan melalui Permenristekdikti.Suara menteri tetap 35\%, namun kami mulai 
mengelompokkan sesuai dengan aturan, mulai dari penjaringan, penyaringan, pemilihan, hingga pelantikan.

Penjaringan dilakukan oleh panitia penjaringan yang telah ditetapkan beradasarkan peraturan menteri.Setelah itu dilakukan penyaringan oleh anggota Senat. Anggota senat antara lain terdiri atas rektor, para wakil rektor, dekan, para wakil guru besar, wakil bukan guru besar, dan ketua lembaga dalam masalah akademik, yaitu lembaga penelitian dan lembaga pengabdian pada masyarakat.Setelah melalui tahap itu, tiga nama calon diserahkan ke Kementerian dan dilakukan penelusuran terhadap track record mereka. Penelusuran ini biasanya melibatkan Irjen dan Dirjen.Baru setelah itu dilakukan pemilihan bersama dengan suara menteri 35\% dan anggota senat 65\%. Lahirnya UU No. 12 Tahun 2012 tentang Pendidikan Tinggi (UU Pendidikan Tinggi).Berdasarkan Undang-Undang ini, perguruan tinggi swasta (PTS) tak sepenuhnya lepas dari tanggung jawab Menteri.Tentang pendirian misalnya, Pasal 60 ayat (2) UU Pendidikan Tinggi tegas menyebutkan PTS didirikan setelah mendapat izin Menteri Pendidikan dan Kebudayaan.Selain kewenanganMenteri,Undang-Undang ini juga menyinggung tentang Badan Penyelenggara. Sehingga aturan dasar harus merujuk kepada keputusan menteri dan tidak bisa dilakukan secara terpisah.

Berdasarkan hasil pra survei pemilihan Rektor sudah pernah dilakukan dalam periode sebelumnya, sekarang periode tersebut sudah memasuki masa akhir. Sehingga perlu dilakukan pemilihan Rektor baru. Tahapan pemilihan Rektor sudah berlangsung. Pemilihan ini selanjutnya digunakan sebagai sarana estafet kepemimpinan selanjutnya. Jika semua elemen dapat bertindak profesional dalam pemilihan Rektor IKI-PGRI Pontianak, maka tidak perlu khawatir karena kebebasan berpendapat merupakan hak setiap individu sejak dilahirkan yang telah dijamin oleh konstitusi. Oleh karena itu, harusnya Negara Republik Indonesia sebagai negara hukum dan demokratis berwenang untuk mengatur dan melindungi pelaksanaannya secara khusus Pemilihan Rektor IKIP PGRI Pontianak.

Atas dasar kondisi tersebut, penulis ingin mengetahui informasi lebih lanjut mengenaiimplementasi prinsip-prinsip demokrasidalam pemilihan rektor IKIP PGRI Pontianak. Hal inilah yang mendorong penulis untuk melakukan penelitian lebih lanjut mengenai: “Implementasi Prinsip-prinsip Demokrasi dalam Pemilihan Rektor IKIP PGRI Pontianak", dengan masalah umumnya sebagai berikut 1) Apa saja bentuk prinsip-prinsip demokrasi dalam pemilihan rektor IKIP PGRI Pontianak?, 2) Apa wujud pelaksanaan demokrasi di IKIP PGRI Pontianak?, 3) Apa saja faktor yang mempengaruhi implementasi prinsip-prinsip demokrasi dalam pemilihan rektor IKIP PGRI Pontianak? 


\section{METODE}

Pendekatan penelitian yang digunakan adalah pendekatan kualitatif dengan bentuk penelitiannya adalah penelitian terapan. Penelitian terapan berfungsi untuk mencari solusi tentang masalah-masalah tertentu. Penelitian terapan merupakan penelitian yang dikerjakan dengan maksud untuk menerapkan, menguji, dan mengevaluasi kemampuan suatu teori yang diterapakan dalam pemecahan permasalahan praktis. Menurut Jujun S. Sumantri (2008:75) penelitian terapan merupakan penelitian yang bertujuan untuk memecahkan masalah-masalah praktis. Penelitian dilakukan di IKIP PGRI Pontianak, alamatnya berada di Jalan Ampera Pontianak Provinsi Kalimantan Barat. Penentuan lokasi penelitian ini dilaksanakan karena menurut penjelasan dari pihak Kampus belum pernah dilakukan penelitian di di IKIP PGRI Pontianak, alamatnya berada di jalan Ampera Pontianak Provinsi Kalimantan Barat. Waktu penelitian ini dilaksanakan sesuai dengan kalender aktif pendidikan yang berlaku di IKIP PGRI Pontianak. Subyek penelitian terdiri dari Dosen-dosen di lingkungan IKIP PGRI Pontianak, Rektor, Wakil rektor 1 dan 2, dan beberapa karyawan lainnya yang bekerja di IKIP PGRI Pontianak.Teknik pengumpulan data yang digunakan adalah teknik komunikasi langsung, teknik observasi langsung, dan teknik studi dokumenter dengan alat pengumpul datanya terdiri dari pedoman wawancara, pedoman observasi , dan dokumen. Teknik analisis data yang dilekukan adalah secara kualitatif yaitu dengan pengumpulan data,reduksi data, penyajian data dan verifikasi atau penarikan kesimpulan.

\section{HASIL PENELITIAN DAN PEMBAHASAN}

\section{Prinsip-Prinsip Demokrasi dalam Pemilihan Rektor IKIP PGRI Pontianak}

Prinsip merupakan kaidah atau ketentuan dasar yang harus dipegang dan ditaati. Budiyanto (2007:37) mengemukakan prinsip demokrasi adalah beberapa kaidah dasar yang harus ada dan ditaati oleh negara penganut pemerintahan demokratis. Adapun prinsip-prinsip demokrasi tersebut sebagai berikut:

a. Negara Berdasarkan Konstitusi

Pengertian negara demokratis adalah negara yang pemerintah dan warganya menjadikan konstitusi sebagai dasar penyelenggaraan kehidupan berbangsa dan bernegara. Konstitusi dapat diartikan sebagai undang-undang dasar atau seluruh peraturan hukum yang berlaku di sebuah negara. Sebagai prinsip demokrasi, keberadaan konstitusi sangat penting sebab dalam penyelenggaraan kehidupan bernegara. Konstitusi berfungsi untuk membatasi wewenang penguasa atau pemerintah serta menjamin hak rakyat. Dengan demikian, penguasa atau pemerintah tidak akan bertindak sewenang-wenang kepada rakyatnya dan rakyat tidak akan bertindak anarki dalam menggunakan hak dan pemenuhan kewajibannya. 


\section{b. Jaminan Perlindungan Hak Asasi Manusia}

Hak asasi manusia (HAM) adalah hak dasar atau hak pokok yang dimiliki manusia sejak lahir sebagai anugerah Tuhan Yang Maha Esa. Hak asasi manusia mencakup hak untuk hidup, kebebasan memeluk agama, kebebasan berserikat, berkumpul, dan mengeluarkan pendapat, serta hak-hak lain sesuai ketentuan undang-undang. Perlindungan terhadap HAM merupakan salah satu prinsip negara demokrasi karena perlindungan terhadap HAM pada hakikatnya merupakan bagian dari pembangunan negara yang demokratis.

c. Kebebasan Berserikat dan Mengeluarkan Pendapat

Salah satu prinsip demokrasi adalah mengakui dan memberikan kebebasan setiap orang untuk berserikat atau membentuk organisasi. Setiap orang boleh berkumpul dan membentuk identitas dengan organisasi yang ia dirikan. Melalui organisasi tersebut setiap orang dapat memperjuangkan hak sekaligus memenuhi kewajibannya. Sejarah demokrasi memberikan kesempatan kepada setiap orang untuk berpikir dan menggunakan hati nurani serta menyampaikan pendapat dengan cara yang baik.

d. Adanya Peradilan Bebas dan Tidak Memihak

Peradilan bebas adalah peradilan yang berdiri sendiri dan bebas dari campur tangan pihak lain termasuk tangan penguasa. Pengadilan bebas merupakan prinsip demokrasi yang mutlak diperlukan agar aturan hukum dapat ditegakkan dengan baik. Para hakim memiliki kesempatan dan kebebasan untuk menemukan kebenaran dan memberlakukan hukum tanpa pandang bulu. Apabila peradilan tidak lagi bebas untuk menegakkan hukum dapat dipastikan hukum tidak akan tegak akibat intervensi atau campur tangan pihak di luar hukum oleh karena itu, peradilan yang bebas dari campur tangan pihak lain menjadi salah satu prinsip demokrasi. Peradilan tidak memihak artinya peradilan yang tidak condong kepada salah satu pihak yang bersengketa di muka persidangan. Posisi netral sangat dibutuhkan untuk melihat masalah secara jernih dan tepat Kejernihan pemahaman tersebut akan membantu hakim menemukan kebenaran yang sebenarbenarnya. Selanjutnya, hakim dapat mempertimbangkan keadaan yang ada dan menerapkan hukum dengan adil bagi pihak beperkara.

e. Penegakan Hukum dan Persamaan Kedudukan Setiap Warga Negara di Depan Hukum

Hukum merupakan instrumen untuk menegakkan kebenaran dan keadilan. Oleh karena itu, pelaksanaan kaidah hukum tidak boleh berat sebelah atau pandang bulu. Setiap perbuatan melawan hukum harus ditindak secara tegas. Persamaan kedudukan warga negara di depan hukum akan memunculkan wibawa hukum. Saat hukum memiliki wibawa, hukum tersebut akan ditaati oleh setiap warga negara.

f. Jaminan Kebebasan Pers 
Kebebasan pers merupakan salah satu pilar penting dalam prinsip prinsip demokrasi. Pers yang bebas dapat menjadi media bagi masyarakat untuk menyalurkan aspirasi serta memberikan kritikan dan masukan kepada pemerintah dalam pembuatan kebijakan publik. Di sisi lain, pers juga menjadi sarana sosialisasi program-program yang dibuat pemerintah. Melalui pers diharapkan dapat terjalin komunikasi yang baik antara pemerintah masyarakatBerdasarkan beberapa prinsipprinsip demokrasi, terdapat dua prinsip-prinsip demokrasi dalam pemilihan rektor IKIP PGRI Pontianak sebagai adalah: 1)kebebasan berserikat dan mengeluarkan pendapat, salah satu prinsip demokrasi adalah mengakui dan memberikan kebebasan setiap orang untuk berserikat atau membentuk organisasi. 2)pergantian kekuasaan secara berkala, pergantian kekuasaan secara berkala dapat meminimalisasi penyelewengan dalam pemerintahan seperti korupsi, kolusi, dan nepotisme.

Berdasarkanhasilwawancaradengan calon rektor, ketua senat, sekretaris senat dan anggota panitia IKIP PGRI Pontianak terkait dengan bentuk prinsip-prinsip demokrasi dalam pemilihan rektor IKIP PGRI Pontianak berjalan dengan baik dapat dilihat dari: a) kebebasan berserikat dan mengeluarkan pendapat, sudah terjadi dengan baik, hal ini diketahui berdasarkan hasil wawancara dari beberapa sumber yang menyatakan secara umum lembaga mengizinkan untuk membentuk organisasi kampus, karena dengan membentuk organisasi kampus, mahasiswa akan mendapat banyak kesempatan untuk bertemu dengan orang-orang yang menginspirasi, yang berbeda latar belakang, budaya, etnis, agama, dan pemikiran, b) pergantian kekuasaan secara berkala, sudah terjadi berdasarkan hasil pengamatan dan wawancara dari beberapa sumber, Tujuan pemilihan rektor dilakukan 4 tahun sekali jadi lembaga dapat meminimalisasi terjadi nya korupsi, kolusi dan nepotisme.

\section{Wujud Pelaksanaan Demokrasi di IKIP PGRI Pontianak}

Wujud pelaksanaan demokrasi di IKIP PGRI Pontianakadalahterlaksananya demokrasi memungkinkan warga untuk berpartisipasi, secara langsung atau melalui perwakilan dalam perumusan, pengembangan, dan pembuatan hukum. Demokrasi termasuk praktek-praktek sosial, ekonomi, dan budaya yang memungkinkan untuk kebebasan politik secara bebas dan sama-sama.

Pemilihan dapat dikatakansebagai sebuah aktivitas politik dimana Pemilu merupakan lembaga sekaligus juga Praktis politik yang memungkinkan terbentuknya sebuah perwakilan. Seperti yang telah dituliskan di atas bahwa di dalam negara demokrasi, Pemilu merupakan salah satu unsur yang sangat vital, karena salah satu parameter mengukur demokratis tidaknya suatu negara adalah dari bagaimana perjalanan. Pemilu merupakan salah satu ciri dari bentuk sebuah demokrasi. 
Budiyanto (2007: 37) mengemukakan model-model demokrasi liberal, demokrasi terpimpin, demokrasi sosial, demokrasi partisipasi, demokrasi konstitusional, demokrasi langsung. Fuadi (2010: 34) mengemukakan bahwa demokrasi jika dilihat dari segi bagaimana keterlibatan rakyat dalam suatu proses pengambilan keputusan, konsep negara demokrasi minimal memunculkan tiga macam demokrasi sebagai berikut:

a. Demokrasi langsung

Demokrasi langsung adalah bentuk demokrasi di mana setiap orang untuk memilih suara dalam memutuskan keputusan. Dalam sistem ini, setiap orang mewakili dirinya sendiri dalam memilih suatu kebijakan sehingga mereka memiliki pengaruh langsung pada situasi politik. Sistem demokrasi langsung digunakan pada hari-hari awal demokrasi di Athena dimana ketika ada masalah yang harus diselesaikan, semua orang berkumpul untuk membahasnya. Di era modern sistem ini menjadi tidak praktis karena populasi umum suatu negara cukup besar dan mengumpulkan semua orang di forum adalah hal yang sulit. Selain itu, sistem ini memerlukan partisipasi tinggi masyarakat, sedangkan orang-orang modern cenderung tidak memiliki waktu untuk mempelajari semua masalah politik negara.

b. Demokrasi Perwakilan

Demokrasi perwakilan juga disebut demokrasi tidak langsung (indirect democracy atau representative democracy), adalah suatu sistem politik dengan memberikan hak kepada rakyatnya secara tidak langsung atau dengan melalui para wakilnya untuk ikut serta melakukan kegiatankegiatan kenegaraan di bidang politik. Dalam hal ini terdapat kegiatan kenegaraan tertentu saja yang masih dilakukan secara langsung, misalnya Pemilihan Umum, yang dilakukan oleh rakyat (pemilih) untuk memilih wakil-wakilnya yang akan menjadi anggota lembaga perwakilan rakyat, baik untuk tingkat pusat maupun tingkat daerah. Secara umum Pengertian demokrasi tidak langsung / perwakilan adalah sitem demokrasi yang tidak melibatkan seluruh rakyat tetapi rakyat memberikan kepercayaan kepada para wakilnya untuk membicarakan dan menentukan persoalanpersoalan kenegaraan. Para wakil rakyat ini memiliki kekuasaan untuk membentuk, menyelenggarakan, dan mengawasi jalannya pemerintahan. Karena rakyat diwakili oleh para wakil rakyat, maka demokrasi tidak langsung juga disebut dengan demokrasi perwakilan. Seperti dikutip dari wikipedia Demokrasi perwakilan adalah jenis demokrasi yang didasarkan pada prinsip sedikit orang yang dipilih untuk mewakili sekelompok orang yang lebih banyak, kebalikan dari demokrasi langsung. Contoh dua negara yang menggunakan demokrasi perwakilan adalah Britania Raya (monarki konstitusional) dan Jerman (republik federal).

c. Demokrasi dengan Partai Tunggal 
Negara satu-partai, sistem satu partai, sistem monopartai, atau sistem partai tunggal adalah jenis pemerintahan sistem partai di mana hanya terdapat satu partai politik yang memiliki hak untuk menjalankan pemerintahan. Dalam sistem negara partai tunggal, pemerintah melarang pendirian partai politik lain dan membuat aturan-aturan yang memperkuat pelarangan itu. Partai yang memegang kekuasaan dalam pemerintahan memiliki pembenaran dalam melaksanakan kebijakan satu partainya, diantaranya adalah untuk menjamin persatuan nasional dan keyakinan bahwa partai menjadi sebuah entitas yang "melindungi revolusi" di mana legitimasinya tidak dapat dipertanyakan. Namun dalam tindakanya mengklaim semua yang dilakukan untuk kepentingan rakyat.

Berdasarkan hasil wawancara dengan calon rektor, ketua senat, sekretaris senat dan anggota panitia IKIP PGRI Pontianak terkait dengan wujud pelaksanaan demokrasi di IKIP PGRI Pontianak berjalan dengan baik dapat dilihat dari: a) jujur dan adil,secara umum pelaksanaan pemilihan rektor berjalan dengan jujur dan adil karena dilakukan dengan pemungutan suara melalui anggota senat dan dilaksanakan layaknya pemilihan umum , b) transparan secara umum pemilihan sudah transparan, kita sudah membuat pengumuman mulai dari visi misi calon rektor dan kegiatan-kegiatan yang akan dilaksanakan dalam pemilihan tersebut c) menghadirkan pemimpin yang sesuai dengan harapan, secara umum dari hasil wawancara sesuai harapan, dilihat dari jadwal dan mekanisme yang sudah di atur lewat senat selain itu kriteria pemimpin juga sudah diatur berdasarkan STATUTA IKIP PGRI Pontianak. Secara umum wujud pelaksanaan demokrasi di IKIP PGRI adalah demokrasi perwakilan. Perwakilan yang dimaksud adalah tidak semua dosen mempunya hak pilih, adapun yang memiliki hak memilih adalah anggota senat yang memilih dan unsur pimpinan darikelembagaan yang ada di IKIP PGRI Pontianak.

\section{Faktor Yang Mempengaruhi Implementasi Prinsip-Prinsip Demokrasi dalam Pemilihan Rektor IKIP PGRI Pontianak}

Dalam penelitian ini, dengan mendasarkan telaah/kajian teoritik tentang demokrasi, Anis Ibrahim (2012) mengemukakan prinsip dasar demokrasi itu paling tidak ada lima prinsip yang meliputi meliputi: (a) prinsip keterbukaan,(b)prinsip partisipasi publik, (c) prinsip persamaan/kesetaraan, (d) prinsip kebebasan, (e) prinsip kontrol rakyat terhadap proses kebijakan yang dibuat elite. Lima prinsip dasar demokrasi ini di lokasi penelitianternyatabelum terimplementasikan/belum terlembagakan dengan baik.Barang tentu ada berbagai faktor yang menghambat pelembagaan prinsip dasar demokrasi tersebut.

Anis Ibrahim (2012) mengemukakan fakta empirik (data primer) yang diperoleh di lokasi penelitian maupun fakta normatif (data skunder) dapat diketengahkan bahwa paling tidak ada 5 
(lima) faktor yang menghambat prinsip dasar demokrasi di lokasi penelitian yaitu: a. faktor substansi hukum, b. faktor struktur hukum, c. faktor kultur hukum, d. faktor waktu, dan e. faktor anggaran.

a. Faktor Substansi Hukum

Substansi hukum dibatasi pengertiannya pada peraturan perundang-undangan (peraturan hukum) yang dibentuk oleh lembaga yang berwenang untuk menjalankan fungsi baik itu lembaga pendidikan di tingkat pusat maupun di tingkat daerah. Peraturan hukum ini mulai dari yang berjenis Undang-Undang, Peraturan Pemerintah, Peraturan Presiden, Perda, Peraturan Menteri.

b. Faktor struktur hukum

Struktur hukum di sini diberi pengertian sebagai kelembagaan yang diciptakan oleh sistem hukum yang bersangkutan dengan berbagai macam fungsinya dalam rangka mendukung bekerjanya sistem hukum tersebut. Meski ada yang menyatakan bahwa lembaga hukum merupakan lembaga pendidikan, namun karena eksistensinya dilahirkan dari suatu produk dan ia memiliki fungsi-fungsi dan tugas-tugas di bidang pendidikan, seperti fungsi pembentukan tenaga pendidik yang handal, maka tidak salah jika lembaga pendidikan sejatinya juga merupakan salah satu komponen yang tidak terpisahkan.

c. Faktor kultur hukum

Yang dimaksud dengan kultur hukum adalah berupa nilai-nilai dan sikap-sikap yang merupakan pengikat sistem itu serta menentukan tempat sistem hukum itu di tengah-tengah kultur hukum di lembaga secara keseluruhan. Salah satu sikap warga kampus jika proses partisipasi dosen ditempuh, maka proses pembahasan akan bertele-tele.

d. Faktor waktu

Waktu yang terbatas juga menjadi faktor penyebab tidak terlembagakannya prinsip dasar demokrasi berikutnya dalam proses pembentukan lembaga di lokasi penelitian. Memang tidak semua aturan yang dibentuk selalu terkait dengan keterbatasan waktu untuk menyusun maupun membahasnya. Beberapa aturan ketika sedang disiapakan/disusun di tingkat panitia maupun ketika dibahas tidak ada kendala waktu untuk menyelesaikannya. Keterbatasan waktu penyiapan/penyusuan dan pembahasan aturan tersebut disampaikan oleh semua responden di lokasi penelitian ketika menyusun dan membahas aturan terkait dengan pungutan yang akan diterapkan kepada warga kampus.

e. Faktor Anggaran

Jika ditelisik lebih lanjut alokasi anggaran disuatu lembaga masih sangat minim untuk kegiatan pemilihan Rektor dibanding dengan dana pengelolaan yang digunakan setiap tahunnya. Berapa anggaran untuk pemilu ternyata masing-masing responden atau dosen mengetahui secara 
persisnya. Dengan demikian dalam laporan penelitian ini tidak bisa diketengahkan besaran anggaran yang dipergunakan anggaran yang dibutuhkan. Secara umum dapat diketengahkan bahwa meski sudah ada panitia yang di dalamnya direncanakan sekian jumlah Aturan yang akan dibahas dalam pemilihan terkadang kurang memadai. Dalam perhitungan kasar yang dilakukan oleh panitia dialokasikan untuk 1) pembuatan naskah akademik, 2) perancangan/ perumusan draf ADART, 3) studi banding, 4) kegiatan publikasi dan partisipasi publik, dan 5) pembahasan ADART

Berdasarkanhasilwawancaradengan calon rektor, ketua senat, sekretaris senat dan anggota panitia IKIP PGRI Pontianak terkait dengan faktor yang mempengaruhi implementasi prinsipprinsip demokrasi dalam pemilihan rektor IKIP PGRI Pontianak dapat di kondisikan dengan baik dapat dilihat dari: a) pelaksanaan pemilihan rektor dilakukan dengan asas keterbukaan karena semuanya kita sampaikan lewat rapat maupun dalam pemilihan dan diikuti oleh anggota senat, b) ada mekanisme pemilihan jadi tidak semua dosen ikut dalam pemilihan. c) semua pemilih memiliki persamaan dan kesetaraan tidak ada yang kita beda-bedakan dalam pemilihan rektor. d) Kebebasan menjadi landasan dalam pemilihan rektordengan mengikuti STATUTA IKIP PGRI Pontianak, contohnya saja kebebasan dalam menentukan calon rektror yang mereka pilih. e) Prinsip kontrol terus dilakukan pada tugas dan kinerja rekor terpilih supaya tidak ada hal yang tidak di inginkan terjadi di lembaga.

\section{SIMPULAN}

Berdasarkanhasil penelitian dan deskripsi yang telah dilakukan, maka dapat disimpulkan secara umum implementasi prinsip-prinsip demokrasi dalam pemilihan rektor IKIP PGRI Pontianak sudah berjalan dengan baik. Sedangkan secara khusus dalam setiap fokus penelitian adalah sebagai berikut: Bentuk Prinsip-Prinsip Demokrasi dalam Pemilihan Rektor IKIP PGRI Pontianakberjalan dengan baik dapat dilihat dari: a) kebebasan berserikat dan mengeluarkan pendapat, sudah terjadi dengan baik, b) pergantian kekuasaan secara berkala, sudah terjadi berdasarkan hasil pengamatan dan wawancara dari beberapa sumber, Tujuan pemilihan rektor dilakukan 4 tahun sekali jadi lembaga dapat meminimalisasi terjadi nya korupsi, kolusi dan nepotisme; Wujud Pelaksanaan Demokrasi di IKIP PGRI Pontianakberjalan dengan baik dapat dilihat dari: a) jujur dan adil, b) transparan secara umum pemilihan sudah transparan, c) menghadirkan pemimpin yang sesuai dengan harapan, secara umum dari hasil wawancara sesuai harapan, dilihat dari jadwal dan mekanisme yang sudah di atur lewat senat selain itu kriteria pemimpin juga sudah diatur berdasarkan STATUTA IKIP PGRI Pontianak. Secara umum wujud pelaksanaan demokrasi di IKIP PGRI adalah demokrasi perwakilan. Perwakilan yang dimaksud 
adalah tidak semua dosen mempunya hak pilih, adapun yang memiliki hak memilih adalah anggota senat yang memilih, yayasan dari PGRI, unsur pimpinan darikelembagaan yang ada di IKIP PGRI Pontianak; Faktor Yang Mempengaruhi Implementasi Prinsip-Prinsip Demokrasi dalam Pemilihan Rektor IKIP PGRI Pontianak dapat di kondisikan dengan baik dapat dilihat dari: a) pelaksanaan pemilihan rektor dilakukan dengan asas keterbukaan karena semuanya kita sampaikan lewat rapat maupun dalam pemilihan dan diikuti oleh anggota senat, b) ada mekanisme pemilihan jadi tidak semua dosen ikut dalam pemilihan. c) semua pemilih memiliki persamaan dan kesetaraan tidak ada yang kita beda-bedakan dalam pemilihan rektor. d) Kebebasan menjadi landasan dalam pemilihan rektordengan mengikuti STATUTA IKIP PGRI Pontianak, contohnya saja kebebasan dalam menentukan calon rektor yang mereka pilih. e) Prinsip kontrol terus dilakukan pada tugas dan kinerja rektor terpilih supaya tidak ada hal yang tidak di inginkan terjadi di lembaga.

\section{DAFTAR PUSTAKA}

Anis Ibrahim(2012). Faktor-Faktor Yang Menghambat Implementasi Prinsip Dasar Demokrasi dalam Proses Pembentukan Peraturan Daerah (Studi Di Kabupaten Lumajang). Diakses Selasa, 03 April 2012.

Arikunto, S. (2010). Prosedur Penelitian, Suatu Pendekatan Praktik. Jakarta: Rineka Cipta.

Budiyanto. (2007). Pendidikan Kewarganegaraan untuk SMA Kelas XI. Jakarta: PT. Erlangga

Darmadi, H. (2007). Pendidikan Pancasila dan Konsep Dasar dan Implementasi Bandung : Alfabeta

Darmadi, H. (2010). Pengantar Pendidikan Kewarganegaraan. Bandung : Alfabeta

Fuadi, M (2010). Konsep Negara Demokrasi. Bandung: PT. Refika Aditama

Rianto, H., \& Moad, N. (2016). PERSEPSI MAHASISWA TENTANG DEMOKRASI DI KALIMANTAN BARAT. Sosial Horizon: Jurnal Pendidikan Sosial, 2(2), 158-172.

http://journal.ikippgriptk.ac.id/index.php/sosial/article/view/102.

Philip B Kurland dan Ralph Lerner (eds.) jurnal bahasa asing The Founders' Constitution(Chicago: University of ChicagoPress, 1987), atau http://pressubs.uchicago.edu/ founders/ (diakses tanggal 27 Juni 2006) 